Click www.researchjournal.co.in/online/subdetail.html to purchase.

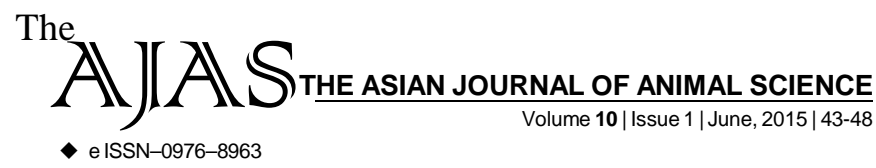

DOI : 10.15740/HAS/TAJAS/10.1/43-48 Visit us | www.researchjournal.co.in $\mathbf{S}$

RESEARCH ARTICLE.

\title{
Relative contribution of rural women to animal husbandry activities in Haryana
}

ANIKA MALIK, GAUTAM AND KAMALDEEP

Author for Corresponding -

\section{ANIKA MALIK}

Department of Veterinary and Animal Husbandry Extension

Education, College of Veterinary

Sciences, Lala Lajpat Rai

University of Veterinary and

Animal Sciences, HISAR

(HARYANA) INDIA

Email: anikadhundwal@gmail.com

See end of the article for

Coopted authors'
ABSTRACT...... India is predominantly an agrarian society where animal husbandry forms the backbone of national economy. Many of the important tasks in animal husbandry are performed by women besides their responsibilities as home makers and caring of animals is considered as an extension of domestic activities. This study emphasized the relative contribution of rural women in various animal husbandry activities. The study was conducted in Hisar district of Haryana state. 30 women farmers were chosen from each selected villages thus constituting a sample size of 120 by simple lottery method. Gender inequality in terms of contribution to animal keeping activities was assessed. The role performance was assessed by documenting the contribution of both men and women family members in the routine activities (feeding, management, dung disposal and milking) and non-routine activities (healthcare, breeding and animal marketing) associated with animals. The average time spent in the animal husbandry activities by a household was 6.76 hours. Out of this women farmer's contribution was 5.17 hours. The contribution of the male members of the family was lesser, and was restricted for most part to the feeding and management activities. They contributed a little in the dung and milk management. Women reportedly contributed significantly (64\% of the feeding, $76 \%$ of the management, $100 \%$ in dung disposal and $89 \%$ in the milking of animals). And in case of non-routine activities there were distinct roles adopted by men and women. The roles appear strictly gender demarcated with women being assigned the activities that have to do with routine care of animals at home. It appears that patriarchal system is prevalent and is facilitating male dominance.

KEY WORDS....... Livestock, Rural women, Role performance

HOW TO CITE THIS ARTICLE - Malik, Anika, Gautam and Kamaldeep (2015). Relative contribution of rural women to animal husbandry activities in Haryana. Asian J. Animal Sci., 10(1) : 43-48.

ARTICLE CHRONICLE - Received : 05.04.2015; Revised : 25.04.2015; Accepted : 10.05.2015 